\title{
When Children Draw vs When Children Don't: Exploring the Effects of Observational Drawing in Science
}

\author{
Jill E. Fox ${ }^{1}$, Joohi Lee ${ }^{2}$ \\ ${ }^{1}$ University of Houston, Victoria, Victoria, USA \\ ${ }^{2}$ University of Texas at Arlington, Arlington, USA \\ Email: foxje@uhv.edu, joohilee@uta.edu
}

Received May $3^{\text {rd }}, 2013$; revised June $4^{\text {th }}, 2013$; accepted June $12^{\text {th }}, 2013$

Copyright (C) 2013 Jill E. Fox, Joohi Lee. This is an open access article distributed under the Creative Commons Attribution License, which permits unrestricted use, distribution, and reproduction in any medium, provided the original work is properly cited.

\begin{abstract}
The purpose of this study was to investigate how kindergarten children's observational drawings impact their information retention. This research was conducted in an urban school in a large metropolitan area in the southwestern United States. Forty-two kindergarten children participated in this study; approximately $97 \%$ of them qualified for free and/or reduced lunch. For this study, children's retention of factual information was compared using a paired t-test of when they drew and when they didn't. Children scored higher on all 7 items - descriptions of observation, location, action, color, size, shape, and sound - when they drew than when they didn't. Findings were statistically significant for descriptions of observation ( $t$ $=3.08, p=.00)$ and location $(\mathrm{t}=2.36, p=.02)$.
\end{abstract}

Keywords: Observation; Observational Drawing; Scientific Drawing

\section{Introduction}

Observation is a fundamental skill for successful scientific inquiry (National Research Council, 1996). It has been emphasized that young children should practice observation skills at an early age (NRC, 1996) and they need to learn how to observe in a systematic manner. Several educators and researchers have recommended that teachers of young children employ various strategies to record children's observations including drawing (Samarapungavan, Patrick, \& Mantzicopoulous, 2011; Quigley, Pongsanon, \& Akerson, 2010; Bosse, Jacobs, \& Anderson, 2009). However, there has been limited research on how drawing activities affect young children's observational experiences. This study is an exploratory study aiming to present how drawing impacts children's observation skills during scientific inquiry.

\section{Theoretical Framework}

\section{Observation as a Fundamental Inquiry Skill}

"Science as Inquiry" is the very first of the six content standards of the National Science Education (NSE). NRC (1996) has proposed that children in $\mathrm{K}$ through grades 12 should develop the abilities to do scientific inquiry and understand scientific inquiry as the major goal of science education. Inquiry is defined as "a very careful and systematic method of exploring the unknown so that discoveries are made" (Abruscato, 2004: p. 46). To be able to successfully engage in inquiry, young children should obtain basic inquiry process skills which include observation as a key component.

The importance of observation has been nationally and internationally highlighted in existing literatures as well as na- tional and state standards. Internationally, observation is a component of early childhood and preschool curricula in Greece (Kallery, Psillos, \& Tselfes, 2009) and Australia (Howitt, Lewis, \& Upson, 2011), among other countries. As indicated above, in America, observation is considered to be one of critical scientific inquiry skills that children should begin to develop in early education (National Committee on Standards for Science Education, 1996). Several American states have identified observation as a basic scientific skill to be introduced in the kindergarten science curriculum (California Department of Education, 1998; Connecticut State Department of Education, 2004; Texas Education Agency, 1998; Virginia Department of Education, 2009) and it has been integrated throughout state standards to make it mandatory. Teachers of young children have been encouraged and required to provide students observational practices throughout the curriculum especially in science learning. However, there has been deficiency of research on how to promote children's observational skills in early childhood. This study is to provide evidence based empirical data to teachers of young children how to promote observation skills in a structured manner by integrating drawing activities.

\section{Drawings as Observational Records}

Professional organizations such as NRC (1996) and National Council of Teachers of Mathematics (NCTM, 2001) emphasize encouraging children to use various methods to organize, record, and communicate their thoughts, ideas, and observations. According to Howes (2007), observational practice has little meaning for young children without recording what they observe. Many times, children at upper elementary education and middle/high school levels record their observations in print or in writing, frequently in a science journal (Dove, Everett, \& 
Preece, 1999). However, young children with limited proficiency in formal reading and writing often experience frustration trying to write in a journal. To sensitively respond to the needs of young children, additional forms of representation should be encouraged for recording their observations. For example, an audio recording of the child's description of the observation, a photograph, or a drawing would all provide documentation of the experience. In this study, researchers utilized children's drawings, the most frequently used representation tool in early childhood. Drawing is one of concrete and effective ways for young children attempting to record their observations (Kepler, 1998; Brooks, 2003).

Some educators might debate the use of drawings as a recording tool of science observations since many children use drawings to represent their thoughts and emotions instead of factual observations. Though young children most often engage in drawing as a creative activity or as a tool to express their feelings/ideas, Kaatz (2008) claims that even at a young age, children are able to understand the differences between scientific and creative drawing. Based on her research, children are easily able to distinguish scientific drawings from creative and imaginative drawings.

When children are engaged in the drawing process to represent their observations, their observational and analytical skills (Jolley, 2010), including spatial visualizations, orientations and relation (Brooks, 2009), increase. In addition, children's ability to describe factual information based on their scientific observation increases (Fox, 2010). In the current study, a quasi-experimental model was applied to quantitatively investigate how effective kindergarten children's observational drawings were as they attempted to recall and to describe the information they observed.

\section{Methods}

\section{Research Setting and Participants}

This research was conducted in an urban school in a large metropolitan area in the southwestern United States. Approximately $97 \%$ of the children attending this school qualify for free and/or reduced-cost lunch. Participants in this study were 42 children enrolled in 8 different kindergarten classes at the school ( 27 boys and 15 girls). All of the children were attending kindergarten for the first time and had turned five years of age on or before October 1 of the current school year. Regarding ethnicity, 18 children identified as African-American, 21 as Latino, one as Asian-American, and two as Anglo.

\section{Data Collection and Analysis}

Each child participating in this study conducted two observations of live animals. The children were randomly divided into a drawing and a non-drawing group; children from each ability group were evenly distributed across the drawing and nondrawing groups. Interviews were conducted by the primary researcher, an early childhood professor and former kindergarten teacher, who had been volunteering in the kindergarten classrooms weekly for seven months. Interview questions (see Appendix) were developed collaboratively by the researchers and the classroom teachers and were based on the role of observation in the science curriculum. For their first observation, individual children were asked to join the researcher at a table and be a scientist, making "a careful observation" of two zebra finches in a bird cage. When the children indicated that they had finished observing, each child in the non-drawing group was asked a series of questions (Appendix) about what he or she had seen, while each child in the drawing group was given a sheet of paper and a set of markers and asked to draw what he or she had seen. When the child had completed his/her drawing, the same series of questions was asked by the researcher. For both groups of children, the birds remained in full view on the table so that the children could look again as needed. During the following week, the same process was repeated with a reversal of the drawing and non-drawing groups and a different animal for the children to observe (a box turtle in a terrarium).

An audio recording was made of each child's responses to the series of interview questions. The recordings were transcribed each day after the interviews were concluded. The researchers reviewed the transcripts daily and began to identify patterns and categories in the children's responses. The transcripts were also reviewed by one of the classroom teachers and a second early childhood professor to confirm the patterns and categories identified by the researcher.

In reviewing the interview transcripts, each answer was quantified using a three-point scale: 0 for an inaccurate or fantasy answer irrelevant to the actual answer, .5 for a partially accurate answer, and 1 for an accurate answer. Answers were graded on seven major questions about descriptions of observation, location, action, color, size, shape, and sound. To compare the mean score differences on each item between when children drew and when children didn't draw, a paired-t test was calculated.

\section{Results}

Results showed that children scored higher on all of the categories (description of observation, location, action, color, size, shape, and sound) when they drew their observations. As Table 1 shows, children scored higher on all items (i.e., description of observation, location, action, color, size, shape, and sound) when they drew than when they did not. Children in both groups showed the highest scores on describing their observation (See Tables 1 and 2) and lowest on the item associated with description of size when they did not draw $(M=.50$, $S D=.30)$ and when they drew $(M=.54, S D=.28)$.

Table 2 presents mean differences of children's information retention scores between when they drew and when they did not.

Table 1.

Descriptive statistics of non-drawing vs drawing.

\begin{tabular}{ccc}
\hline & \multicolumn{2}{c}{$M(S D)$} \\
\hline Items & Non-drawing & Drawing \\
\hline Description of observation & $.81(.34)$ & $.95(.20)$ \\
Description of location & $.74(.36)$ & $.86(.30)$ \\
Description of action & $.78(.36)$ & $.86(.30)$ \\
Description of color & $.87(.31)$ & $.93(.22)$ \\
Description of size & $.50(.30)$ & $.54(.28)$ \\
Description of shape & $.78(.39)$ & $.87(.32)$ \\
Description of sound & $.78(.37)$ & $.86(.31)$ \\
\hline
\end{tabular}


Children earned highest gains on description of observation (M Diff $=.13$ ) and the second highest score differences were found in the category of description of location $(M$ Diff $=.11)$. The lowest score difference was found on description of size $(M$ Diff $=.03)$.

As Table 3 presents, a paired t-test showed that there were statistically significant mean differences found on "description of observation $(\mathrm{t}=3.08, p=.00)$," and "description of location $(\mathrm{t}=2.36, p=.02)$ " between when children drew their observation and when they didn't. The rest of 5 items (e.g., descriptions of action, color, size, shape, and sound) were not found to be statistically significant.

\section{Findings}

The major findings of this study are: 1) the difference in children's scores on description of observation was found to be statistically significant between when they drew and when they didn't, favoring children in a drawing group; and 2) the difference in children's scores on description of location was found

Table 2.

Mean difference and standard error on each item.

\begin{tabular}{cccc}
\hline & Items & M Diff & SD Error M \\
\hline $\begin{array}{c}\text { Pair 1 (non-drawing } \\
\text { vs drawing) }\end{array}$ & $\begin{array}{c}\text { Description of } \\
\text { observation }\end{array}$ & -.13 & .04 \\
$\begin{array}{c}\text { Pair 2 (non-drawing } \\
\text { vs drawing) }\end{array}$ & Description of location & -.11 & .04 \\
$\begin{array}{c}\text { Pair 3 (non-drawing } \\
\text { vs drawing) }\end{array}$ & Description of action & -.07 & .06 \\
$\begin{array}{c}\text { Pair 4 (non-drawing } \\
\text { vs drawing) }\end{array}$ & Description of color & -.05 & .04 \\
$\begin{array}{c}\text { Pair 5 (non-drawing } \\
\text { vs drawing) }\end{array}$ & Description of size & -.03 & .05 \\
$\begin{array}{c}\text { Pair 6 (non-drawing } \\
\text { vs drawing) }\end{array}$ & Description of shape & -.08 & .06 \\
$\begin{array}{c}\text { Pair 7 (non-drawing } \\
\text { vs drawing) }\end{array}$ & Description of sound & -.07 & .04 \\
\hline
\end{tabular}

Note: $\mathrm{M}$ Diff $=$ Mean Difference.

Table 3.

A paired t-test on non-drawings vs drawings.

\begin{tabular}{cccc}
\hline & Items & $\mathrm{t}$ & $p$ \\
\hline $\begin{array}{c}\text { Pair 1 (non-drawing } \\
\text { vs drawing) } \\
\begin{array}{c}\text { Pair 2 (non-drawing } \\
\text { vs drawing) }\end{array}\end{array}$ & $\begin{array}{c}\text { Description of } \\
\text { observation } \\
\text { Description of } \\
\text { location }\end{array}$ & 3.08 & $.00^{* *}$ \\
$\begin{array}{c}\text { Pair 3 (non-drawing } \\
\text { vs drawing) }\end{array}$ & Description of action & 1.27 & .20 \\
$\begin{array}{c}\text { Pair 4 (non-drawing } \\
\text { vs drawing) }\end{array}$ & Description of color & 1.18 & .24 \\
$\begin{array}{c}\text { Pair 5 (non-drawing } \\
\text { vs drawing) }\end{array}$ & Description of size & -.70 & .48 \\
$\begin{array}{c}\text { Pair 6 (non-drawing } \\
\text { vs drawing) }\end{array}$ & Description of shape & 1.41 & .16 \\
$\begin{array}{c}\text { Pair 7 (non-drawing } \\
\text { vs drawing) }\end{array}$ & Description of sound & 1.59 & .11 \\
\hline
\end{tabular}

${ }^{*}$ Significant at .05 level; ${ }^{* *}$ Significant at .001 level. to be statistically significant between when they drew and when they didn't, again favoring children in a drawing group. In fact, children scored higher on all of seven items (descriptions of observation, location, action, color, size, shape, and sound) when they drew compared to when they didn't draw during a science observation. Although the first two items (description of observation and location) were found to be statistically significant, scientific observational drawings also helped children retain factual information associated with action, color, size, shape, and sound.

\section{Discussion}

Drawing as an activity in the kindergarten curriculum is most often associated with creativity. Edwards, Gandini, and Forman (1998) identify drawing as one of the languages children use for communication. Kindergarten teachers encourage children to use their imaginations when they draw and to communicate thoughts, impressions, and feelings in their artwork. Just as children learn to write for different purposes, however, they can also learn to draw to communicate both the literal and the imaginary (Kaatz, 2008). Children's emergent understanding of science may benefit from this distinction.

Divergent thinking and creativity are typically encouraged in the kindergarten classroom and curriculum while scientific observation is dependent on literal thinking and logical reasoning. Accurate observations are those that carefully distinguish what was actually observed from ideas and speculations about the subject and the process (American Association for the Advancement of Science, 1997).

In this study, drawing objects that were seen in the observation appears to have supported the children's retention of information about what was actually there while restricting speculation or interpretation about the animals and their habitats. Nigel, for example, having drawn his observation of the box turtle, answered the question about its size by saying, "It looks like $\cdots$ small." His answer to the same question after not drawing his observation of the birds lacked this focus: "Uh, this big. And they're birds $\cdots$ you're their mom $\cdots$ and this white thing right there. What is that?" The children who drew economized during their interviews in ways that the majority of the children could not when they did not draw. Drawing focused the children's attention on what was there and they were able to omit hypothetical questions and irrelevant interjections. As Kaatz (2008) indicated, children are able to differentiate between imaginative and factual drawings. When using drawing as a record of observations, it is recommended that teachers remind children that they are to draw their observations as a scientist and that their drawings should be factual.

One of the limitations of this study is associated with the question on "size" (how big is it?) the researchers used in this study. Without a referent it is challenging for children to respond to the question on size. A couple of children answered using standard measurement units (e.g., 5 feet, 3 inches) which are out of range. For example, the size of a fish was refereed to 5 feet which was about 2.5 inches. This might be the reason that children scored lowest on "size" in both groups (drawing and non-drawing). Thus, it is recommended for future researchers to consider utilizing a referent for comparison purpose to determine the size of objects.

It is also recommended that future research on this topic be qualitative. This study is intended to rationalize the thoughts 
behind children's responses. Therefore, it is necessary to further analyze children's responses by asking "why" questions to obtain information on the rationales behind their responses.

\section{Conclusion}

Although additional study is needed to determine exactly why drawing helps to keep children focused during their observations, our findings suggest that drawing does play an important role in helping children to retain more factual information when they utilize it during science observations. Professional scientists in all fields draw upon disciplinary knowledge and understanding of the environment to learn from their observations, and these must be learnt and practiced like any other working skill (Alden, 2009). Focused observations in which children use drawing to record what they see provide the foundation upon which the skills and abilities needed for scientific inquiry are built.

\section{REFERENCES}

Abruscato, J. (2004). Teaching children science. Boston, MA: Pearson Education.

Alden, A. (2009). What is observing? An explanation of observation. http://geology.about.com/od/activitiesbasics/a/observation.htm

American Association for the Advancement of Science (1997). Resources for scientific literacy: Professional development. New York: Oxford University Press.

Bosse, S., Jacobs, G., \& Anderson, T. L. (2009). Science in the air. Young Children, 64, 10-15.

Brooks, M. (2003). Drawing to learn. NAEYC Beyond Journal. http://www.naeyc.org/files/yc/file/200309/DrawingtoLearn.pdf

Brooks, M. (2009). Drawing, visualization and young children's exploration of "Big Ideas." International Journal of Science Education, 31 319-341. doi:10.1080/09500690802595771

California Department of Education (1998). Science content standards for California public schools.

http://www.cde.ca.gov/be/st/ss/documents/sciencestnd.pdf

Connecticut State Department of Education (2004). Core science curriculum framework.

http://www.sde.ct.gov/sde/cwp/view.asp?a=26188q=320890

Dove, J. E., Everett, L. A., \& Preece, P. F. W. (1999). Exploring a hydrological concept through children's drawings. International Journal of Science Education, 21, 485-497.

doi:10.1080/095006999290534

Eberbach, C., \& Crowley, K. (2009). From every day to scientific observation: How children learn to observe the biologist's world. Review of Educational Research, 79, 39-68.

doi:10.3102/0034654308325899
Edwards, C., Gandini, L., \& Forman, G. (1998). The hundred languages of children: The Reggio Emilia approach advanced reflections (2nd ed.). Westport, CT: Ablex.

Ford, D. (2005). The challenges of observing geologically: Third graders' descriptions of rock and mineral properties. International Journal of Science, 89, 276-295.

Fox, J. E. (2010). The role of drawing in kindergarteners' science observations. International Research Journal for Art in Early Childhood Education, 2.

Howes, E. V. (2007). Educative experiences and early childhood science education: A Deweyan perspective on learning to observe. Teaching and Teacher Education, 24, 536-549. doi:10.1016/j.tate.2007.03.006

Howitt, C., Lewis, S., \& Upson, E. (2011). "It's a mystery!" a case study of implementing forensic science in preschool as scientific inquiry. Australasian Journal of Early Childhood, 36, 45-55.

Jolley, R. P. (2010). Children and pictures: Drawing and understanding. West Sussex: Wiley-Blackwell.

Kaatz, K. (2008). A walk in the "tall, tall grass." Science and Children, 45, 28-31.

Kallery, M., Psillos, D., \& Tselfes, V. (2009). Typical didactical activeties in the Greek early years science classroom: Do they promote science learning? International Journal of Science Education, 31, 1187-1204. doi: $10.1080 / 09500690701824850$

Kepler, L. (1998). Hands-on science: Journals of science. Instructor, $108,82-83$

National Committee on Science Education Standards (1996). National science education standards. Washington DC: The National Academies Press.

Quigley, C., Pongsanon, K., \& Akerson, V. L. (2010). If we teach them, they can learn: Young students views of nature of science aspects to early elementary students during an informal science education program. Journal of Science Teacher Education, 21, 887-907. doi:10.1007/s10972-009-9164-5

Samarapungavan, A., Patrick, H., \& Manticopoulos, P. (2011). What kindergarten children learn in inquiry-based science classrooms. Cognition and Instruction, 29, 416-470. doi:10.1080/07370008.2011.608027

Schulte, C. M. (2011). Verbalization in children's drawing performances: Toward a metaphorical continuum, of inscription, extension, and re-inscription. Studies in Art Education, 53, 20-34.

Shephardson, D. P., \& Britsch, S. J. (2001). The role of children's journals in elementary science activities. Journal of Research in Science Teaching, 38, 43-69. doi:10.1002/1098-2736(200101)38:1<43::AID-TEA4>3.0.CO;2-I

Texas Education Agency (1998). Texas essential knowledge and skills. http://ritter.tea.state.tx.us/rules/tac/chapter112/index.html

Virginia Department of Education (2009). Virginia standards of learning.

http://www.doe.virginia.gov/testing/sol/standards_docs/science/2010 /complete/stds_all_science.pdf

\section{Appendix}

\section{Interview Questions}

Tell me what you see.

Where is it in the terrarium? [fish bowl?]

What is it doing?

What color is it?

How big it is?

What shape is it?

Is there anything else you'd like to tell me about what you are seeing? 